BASINDO : Jurnal Kajian Bahasa, Sastra Indonesia, dan Pembelajarannya

Volume 3 Nomor 1, 2019

Journal homepage : http://journal2.um.ac.id/index.php/basindo

\title{
MEDIA AUDIO VISUAL UNTUK PEMBELAJARAN MUSIKALISASI PUISI
}

\author{
Maria Tina Septiani, Muakibatul Hasanah* \\ Universitas Negeri Malang
}

\begin{tabular}{|c|c|}
\hline $\begin{array}{l}\text { A R T I C L E } \\
\text { I N F O }\end{array}$ & A B S T R A C T \\
\hline $\begin{array}{l}\text { Article history: } \\
\text { Received: } 20 \text { Jul } 2018 \\
\text { Accepted: 12 Sep } 2018 \\
\text { Published: } 31 \text { May } 2019 \\
\text { Kata Kunci: } \\
\text { media, audio visual, } \\
\text { pembelajaran, } \\
\text { musikalisasi puisi. } \\
\text { Keyword: } \\
\text { media, audio visual, } \\
\text { learning, poetry } \\
\text { musicalize. }\end{array}$ & $\begin{array}{l}\text { Penelitian ini bertujuan untuk mengembangkan produk berupa } \\
\text { media audio visual untuk pembelajaran musikalisasi puisi bagi siswa } \\
\text { kelas X SMA yang menarik dan praktis. Penelitian ini menggunakan } \\
\text { rancangan penelitian pengembangan dari model ASSURE oleh } \\
\text { Heinich, dkk. Instrumen yang digunakan adalah pedoman } \\
\text { wawancara dan angket. Hasil dari penelitian pengembangan ini } \\
\text { adalah media audio visual untuk pembelajaran musikalisasi puisi } \\
\text { tergolong sangat valid dan dapat digunakan tanpa revisi. Selain itu, } \\
\text { beberapa saran dan komentar digunakan peneliti untuk melakukan } \\
\text { revisi. } \\
\text { The aim of this study is to develop an interesting and practical audio } \\
\text { visual media for musikalisasi puisi learning for tenth graders. This } \\
\text { study used research and development design with ASSURE model } \\
\text { by Heinich, et al. Instruments that used were interview guideline and } \\
\text { questionnaire. The result of this study was the audio visual media for } \\
\text { musikalisasi puisi learning is very valid and can be used without } \\
\text { revision. Moreover, some suggestions and comments obtained for } \\
\text { product revision. }\end{array}$ \\
\hline
\end{tabular}

\section{PENDAHULUAN}

Pada era globalisasi ini, teknologi berkembang semakin cepat dan pesat. Perkembangan teknologi ini memunculkan berbagai gagasan baru mengenai penggunaannya di segala bidang, salah satunya di bidang pendidikan. Pelaksanaan pendidikan kini dituntut untuk memanfaatkan kemajuan teknologi tersebut demi tercapainya pembelajaran yang efektif. Penggunaan media diharapkan bisa dimanfaatkan secara maksimal (Shinta, Chamalah, \& Arsanti, 2018), namun pada hasil analisis kebutuhan peserta didik mengenai kegiatan pembelajaran musikalisasi puisi, ditemukan bahwa (1) penggunaan media tidak dimaksimalkan dalam pembelajaran musikalisasi puisi, dan (2) kurang menariknya media membuat minat siswa untuk musikalisasi puisi masih kurang.

\footnotetext{
* Corresponding author.

E-mail addresses: maria.tina.septi@gmail.com (Maria Tina Septiani), muakibatul.hasanah.fs@um.ac.id (Muakibatul Hasanah)

ISSN : 2579-3799 (Online) - BASINDO : Jurnal Kajian Bahasa, Sastra Indonesia, dan Pembelajarannya is licensed under Creative Commons Attribution-ShareAlike 4.0 International License (http://creativecommons.org/licenses/BY/4.0/).
} 
Pada pembelajaran bahasa Indonesia, siswa dituntut tidak hanya menganalisis makna dari puisi, namun juga mendemonstrasikan puisi. Maksudnya, siswa mampu membaca dan musikalisasi puisi. Pada tahap ini, siswa harus bisa menganalisis puisi dahulu, barulah bisa mendemonstrasikan puisi. Dalam pembelajaran, acapkali siswa lebih memilih untuk membacakan puisi saja, bukan musikalisasi. Ari (2008:9) mengemukakan bahwa musikalisasi puisi dapat didefiniskan sebagai sarana mengkomunikasikan puisi kepada apresian, melalui persembahan musik (nada, irama, lagu, atau nyanyian).

Dalam penguasaan kompetensi siswa, pembelajaran harus menggunakan media yang menarik, efektif, dan praktis. Menurut Sadiman (2008:7), media pembelajaran adalah segala sesuatu yang dapat digunakan untuk menyalurkan pesan dari pengirim ke penerima pesan. Dari pendapat tersebut, dapat dilihat bahwa media pembelajaran memiliki fungsi yang penting dalam pembelajaran, mengingat tujuan pembelajaran adalah tersampainya pesan dari pengajar kepada peserta didik. Pesan-pesan tersebut diharapkan mampu ditangkap oleh siswa sehingga kompetensi belajar siswa bisa tercapai melalui komunikasi dua arah.

Landasan operasional yang digunakan dalam penelitian ini adalah Kompetensi Dasar 4.16 yang ada dalam Kurikulum 2013 revisi 2016, yaitu mendemonstrasikan (membacakan atau memusikalisasikan) satu puisi dari antologi puisi atau kumpulan puisi dengan memerhatikan vokal, ekspresi, dan intonasi (tekanan dinamik dan tekanan tempo). Kegiatan yang dilakukan siswa terkait kompetensi dasar ini adalah musikalisasi satu puisi dan dinilai dari segi vokal, ekspresi, dan intonasi. Jadi, sebelum siswa musikalisasi puisi, siswa harus terlebih dahulu mengerti makna dari isi puisi tersebut untuk selanjutnya bisa memilih nada, irama, dan instrumentalia yang tepat.

Penelitian terdahulu yang serupa adalah penelitian Endang Astuti (2011). Perbedaannya dengan penelitian ini adalah produk yang dikembangkan pada penelitian tersebut adalah film, sedangkan pada penelitian ini berupa aplikasi. Penelitian lain yang serupa adalah penelitian Siti Aminah, Syahwani Umar, dan Andi Usman (2016), perbedaannya adalah karena produk hanya berisi materi saja. Lalu, penelitian oleh Fatkhul Aziz (2013) berbeda dengan penelitian ini karena sasaran media adalah untuk siswa kelas IX SMP, sedangkan penelitian ini sasaran medianya adalah siswa kelas X SMA.

Berdasarkan uraian di atas, tujuan penelitian ini adalah mengembangkan produk berupa media audio visual untuk pembelajaran musikalisasi puisi bagi siswa kelas X SMA yang menarik dan praktis ditinjau dari segi isi, wujud, dan tampilan.

\section{METODE}

Penelitian ini merupakan penelitian pengembangan yang menggunakan model ASSURE oleh Heinich, dkk (1982). Model ASSURE terdiri atas beberapa tahap yang merupakan kepanjangan dari akronim ASSURE, yaitu: (1) menganalisis peserta didik (analyze learners), (2) merumuskan tujuan pembelajaran (state objectives), (3) memilih metode, media, dan bahan ajar (select methods, media, and materials), (4) memanfaatkan metode, media, dan bahan ajar (utilize materials), (5) melibatkan partisipasi pelajar (requires learner participation), dan (6) penilaian dan revisi (evaluate and revise). Dari ke enam tahap model ASSURE, peneliti menggunakan lima tahap, yaitu: (1) menganalisis kebutuhan peserta didik, (2) merumuskan tujuan pembelajaran, (3) mengembangkan media, (4) validasi dan uji coba, dan (5) revisi.

Subjek uji dalam penelitian ini adalah ahli materi, ahli media, praktisi, dan siswa. Penentuan subjek ahli didasarkan pada kriteria (1) memiliki latar belakang pendidikan minimal S1, (2) bidang ahli yang dikuasai yakni bidang sastra (ahli materi), dan (3) bidang ahli yang dikuasai yakni media audio visual (ahli media). Validasi dengan praktisi dilaksanakan dengan guru bahasa Indonesia kelas X SMA Negeri 5 Malang. Penentuan guru sebagai subjek uji praktisi dipilih melalui kroteria tertentu, yaitu (1) latar belakang pendidikan relevan dengan pembelajaran Bahasa dan Sastra Indonesia (minimal S1), (2) sedang mengajar di lembaga pendidikan jenjang SMP/MTs, dan (3) pengalaman mengajar minimal 5 tahun. 
Data dalam penelitian ini adalah data kualitatif dan kuantitatif. Data kualitatif yang diperoleh dari saran dan komentar yang diberikan subjek uji dan data kuantitatif diperoleh dari hasil penilaian subjek uji terhadap media dari beberapa aspek, yaitu isi, wujud, dan tampilan. Instrumen yang digunakan dalam penelitian ini adalah pedoman wawancara dan angket. Pedoman wawancara digunakan peneliti untuk melakukan analisis kebutuhan peserta didik. Angket digunakan peneliti untuk mendapatkan data dari subjek ahli, yaitu ahli materi, ahli media, praktisi, dan siswa. Tingkat penilaian yang digunakan dalam angket adalah skala (Arikunto, 2013:285).

Teknik analisis data pengembangan ini dilakukan dengan (1) mengumpulkan data verbal berupa catatan, komentar, kritik, dan saran ahli dan praktisi yang diperoleh; (2) menghimpun, menyeleksi, dan mengklasifikasikan data verbal berdasarkan kelompok uji; dan (3) menganalisis data dan merumuskan simpulan analisis sebagai dasar revisi. Teknik analisis kuantitatif dilakukan dengan cara mengolah data numerik dari angket validasi, praktisi, dan siswa. Pengolahan data numerik dibagi menjadi dua, yaitu (1) pengolahan data hasil validasi, praktisi, dan lapangan dan (2) pengolahan data untuk menghitung reliabilitas interrater

Data kuantitatif diperoleh dari angket atau kuisioner yang dibagikan kepada ahli, praktisi, dan siswa yang dianalisis dengan rumus yang diadaptasi dari Arikunto (2013:243). Untuk mendapatkan data validasi, pedoman kriteria validitas media dibutuhkan. Hal ini untuk mengetahui seberapa valid media yang sudah dikembangkan.

\section{HASIL}

Pada bagian ini dipaparkan hasil penelitian dan pengembangan. Pada setiap hasil pengembangan dipaparkan deskripsi produk dan hasil uji.

\section{Deskripsi Produk}

Penelitian pengembangan ini menghasilkan produk berupa media audio visual untuk pembelajaran musikalisasi puisi yang ditinjau dari segi isi, wujud, dan tampilan sesuai dengan Kompetensi Dasar 4.16 dalam Kurikulum 2013 revisi 2016, yaitu mendemonstrasikan (membacakan atau memusikalisasikan) satu puisi dari antologi puisi atau kumpulan puisi dengan memerhatikan vokal, ekspresi, dan intonasi (tekanan dinamik dan tekanan tempo). Media yang dikembangkan memiliki tiga komponen di dalamnya, yaitu (1) contoh, (2) materi, dan (3) tugas. Ketiga komponen ini menjadi satu paket lengkap yang bisa digunakan guru dalam pembelajaran musikalisasi puisi. Selain itu, juga terdapat petunjuk penggunaan media guna memudahkan guru dalam menggunakannya.

Media pembelajaran yang dikembangkan berupa media audio visual untuk pembelajaran musikalisasi puisi yang mengacu pada tiga aspek, yaitu (1) isi, (2) wujud, dan (3) tampilan. Berikut ini adalah pemaparan dari produk yang dikembangkan.

Pertama, isi media pembelajaran adalah contoh, materi, dan tugas musikalisasi puisi. Ketiga isi media ini ditampilkan pada menu utama yang bisa dilihat pada Gambar 4.1. Contoh disajikan sesuai dengan macam-macam musikalisasi puisi, yaitu (1) musikalisasi puisi awal, (2) musikalisasi puisi terapan, dan (3) musikalisasi puisi campuran. Tampilan contoh dalam media audio visual bisa dilihat pada Gambar 4.2. Materi yang disajikan adalah seputar musikalisasi puisi, yakni pengertian puisi, pengertian musikalisasi puisi, macam-macam musikalisasi puisi, dan langkah musikalisasi puisi. Tugas yang disajikan bertujuan untuk mengasah kemampuan siswa dalam musikalisasi puisi.

Kedua, wujud media pembelajaran adalah perpaduan antara gambar dan suara yang dikemas dalam aplikasi Microsoft Office Power Point. Aplikasi ini mudah digunakan dan praktis karena hampir semua komputer atau laptop memiliki aplikasi ini. Berkas aplikasi ini dimasukkan ke dalam CD (Compact Disc) untuk selanjutnya dimanfaatkan oleh pengguna.

Ketiga, tampilan media pembelajaran. Media audio visual ini disajikan dengan desain yang menarik dengan memperhatikan perpaduan jenis huruf dan warna latar. Ukuran media ini jika dalam mode Slide Show adalah Widescreen atau 16:9 sehingga saat disambungkan dengan LCD Projector, tampilannya bisa penuh. 


\section{Hasil Validasi}

Data dianalisis berdasarkan tiga aspek, yaitu aspek isi, wujud, dan tampilan media pembelajaran. Analisis data ketiga aspek tersebut diperoleh dari validasi dengan ahli dan praktisi.

Validasi produk dengan ahli materi pembelajaran musikalisasi puisi mengenai aspek isi media pembelajaran difokuskan pada lima kriteria dan menunjukkan persentase sebesar $88,33 \%$ yang berarti sangat valid dan dapat digunakan tanpa revisi.

Validasi produk dengan ahli media audio visual mengenai aspek isi media yang difokuskan pada satu kriteria menunjukkan persentase $83,33 \%$ yang berarti valid dan dapat digunakan namun perlu direvisi kecil. Validasi produk dengan ahli media audio visual mengenai wujud media yang difokuskan pada dua kriteria menunjukkan persentase sebesar 87,5\% yang berarti sangat valid dan dapat digunakan tanpa revisi. Validasi produk dengan ahli media visual mengenai aspek tampilan media yang difokuskan pada dua kriteria menunjukkan presentase sebesar $75 \%$ yang berarti cukup valid dan dapat digunakan namun perlu direvisi kecil.

Validasi produk dengan praktisi mengenai isi media yang difokuskan pada empat aspek menunjukkan persentase $88,89 \%$ yang berarti sangat valid dan dapat digunakan tanpa revisi. Validasi produk dengan praktisi mengenai wujud media yang difokuskan pada satu kriteria menunjukkan persentase sebesar $91,67 \%$ yang berarti sangat valid dan dapat digunakan tanpa revisi. Validasi produk dengan praktisi mengenai wujud media yang difokuskan pada satu kriteria menunjukkan persentase sebesar $91,67 \%$ yang berarti sangat valid dan dapat digunakan tanpa revisi.

Selain data nonverbal berupa skor, ada pula data verbal berupa komentar dan saran terkait isi media pembelajaran. Berikut disajikan komentar dan saran mengenai isi media pembelajaran dari ahli materi dan ahli media dalam Tabel 1.

Tabel 1 Saran Terkait Media Pembelajaran

\begin{tabular}{|c|c|c|c|}
\hline \multirow[t]{2}{*}{ No. } & \multirow[t]{2}{*}{ Komentar dan Saran } & \multicolumn{2}{|l|}{ Ahli } \\
\hline & & Materi & Media \\
\hline 1. & $\begin{array}{l}\text { Perlu ditambahkan langkah penting yang belum ada } \\
\text { dalam media: } \\
\text { a. Memilih puisi } \\
\text { b. Memilih makna/isi puisi } \\
\text { c. Menentukan suasana puisi } \\
\text { d. Menentukan instrumentalia yang sesuai dengan isi dan } \\
\text { suasana puisi }\end{array}$ & $\sqrt{ }$ & \\
\hline 2 & Petunjuk penggunaan perlu disederhanakan & $\checkmark$ & \\
\hline 3 & Alurnya diperbaiki supaya lebih mudah & $\checkmark$ & \\
\hline 4 & $\begin{array}{l}\text { Perlu ditambahkan contoh lagu yang terkenal dengan } \\
\text { pemanfaatan puisi sebagai lirik (contohnya Iwan Fals, } \\
\text { Ebiet G. Ade, dll) }\end{array}$ & & $\sqrt{ }$ \\
\hline
\end{tabular}

\section{Hasil Uji Coba}

Uji coba dilakukan dengan siswa kelas X SMA Negeri 5 Malang. Jumlah siswa yang menjadi responden adalah 34 siswa. Hasil uji coba produk dengan siswa terkait aspek tampilan media yang difokuskan menjadi satu kriteria menunjukkan persentase sebesar 91,67\% yang berarti sangat valid dan dapat digunakan tanpa revisi.

Uji coba produk dengan siswa terkait aspek wujud media yang difokuskan menjadi satu kriteria menunjukkan persentase $89,95 \%$ yang berarti sangat valid dan dapat digunakan tanpa revisi. Uji coba produk dengan siswa terkait aspek tampilan media yang difokuskan menjadi satu kriteria menunjukkan persentase $91,54 \%$ yang berarti sangat valid dan dapat digunakan tanpa revisi.

Analisis Data

34 | BASINDO : Jurnal Kajian Bahasa, Sastra Indonesia, dan Pembelajarannya 
Analisis data merupakan salah satu langkah penting yang dilakukan setelah data dari seluruh proses penelitian sudah terkumpul. Data yang diperoleh dan dianalisis merupakan data mentah sehingga dalam proses analisis ini data akan ditafsirkan. Data validasi dalam penelitian ini mendapatkan hasil dalam bentuk presentasi yang kemudian dinyatakan dalam kalimat yang bersifat kualitatif berdasarkan pedoman kriteria validitas media. Data yang dianalisis merupakan data hasil pengisian angket oleh ahli media, ahli materi, praktisi, dan siswa sebagai responden. Analisis data validasi diuraikan pada Tabel 2 berikut.

Tabel 2 Analisis Data Hasil Validasi dan Uji Coba Produk

\begin{tabular}{lllll}
\hline No. & Validator & $\begin{array}{l}\text { Persentase } \\
\mathbf{( \% )}\end{array}$ & Kriteria & Implementasi \\
\hline 1. & Ahli Materi & 88,33 & Sangat Valid & TR \\
\hline 2. & Ahli Media & 81,67 & Cukup Valid & RK \\
\hline 3. & Praktisi & 90 & Sangat Valid & TR \\
\hline 4. & Responden (Siswa & 92,25 & Sangat Valid & TR \\
\multicolumn{2}{l}{ SMAN 5 Malang) } & & & \\
\hline \multicolumn{2}{l}{ Rerata } & $\mathbf{8 8 , 0 6}$ & Sangat Valid & TR \\
\hline $\begin{array}{l}\text { Keterangan: } \\
\text { TR } \quad \text { tanpa revisi }\end{array}$ & & & \\
RK $\quad$ : revisi kecil & & &
\end{tabular}

Berdasarkan hasil penilaian validasi ahli materi (dapat dilihat pada Tabel 5), persentase validitas media adalah 88,33\% yang berarti sangat valid dan dapat digunakan tanpa revisi. Sementara itu, berdasarkan penilaian validasi ahli media, persentase validitas media adalah 81,67\% yang berarti cukup valid dan dapat digunakan namun perlu direvisi kecil. Berdasarkan penilaian uji coba praktisi, presentasi validitas media adalah 90\% yang berarti sangat valid dan dapat digunakan tanpa revisi. Terakhir, berdasarkan responden yang adalah siswa Kelas X SMAN 5 Malang berjumlah 34 siswa, presentasi validitas media adalah 92,25\% yang berarti sangat valid dan dapat digunakan tanpa revisi.

Dari penilaian para ahli, praktisi, dan responden, rerata persentase validitas media adalah 88,06\%. Dari persentase tersebut, dapat disimpulkan bahwa media audio visual untuk pembelajaran musikalisasi puisi yang dikembangkan oleh peneliti dinyatakan sangat valid dan dapat digunakan tanpa revisi.

\section{PEMBAHASAN}

Produk yang dikembangkan adalah media audio visual untuk pembelajaran musikalisasi puisi. Menurut Sadiman (2008:7), media pembelajaran adalah segala sesuatu yang dapat digunakan untuk menyalurkan pesan dari pengirim ke penerima pesan. Media dapat dijadikan sebagai sebuah sarana dalam penyampaian materi dari pendidik kepada peserta didik. Media yang dikembangkan ini berupa media audio visual. Menurut Sanjaya (2011:211), media audio visual merupakan jenis media yang selain mengandung unsur suara juga mengandung unsur gambar yang dapat dilihat, seperti rekaman video, berbagai ukuran film, slide suara, dan lain sebagainya. Hamalik (dalam Arsyad, 2002:13) mengemukakan bahwa pemakaian media pengajaran dalam proses belajar mengajar dapat membangkitkan keinginan dan minat baru, membangkitkan motivasi dan rangsangan kegiatan belajar, dan bahkan membawa pengaruh-pengaruh psikologis terhadap siswa. Penggunaan media pembelajaran pada tahap orientasi akan membantu keefektifan proses pembelajaran dan penyampaian pesan pada pembelajaran tersebut.

Media audio visual yang dikembangkan sesuai dengan Kompetensi Dasar 4.16 dalam Kurikulum 2013 revisi 2016, yaitu mendemonstrasikan (membacakan atau memusikalisasikan) satu puisi dari antologi puisi atau kumpulan puisi dengan memerhatikan vokal, ekspresi, dan intonasi (tekanan dinamik dan tekanan tempo). Pengembangan media sesuai dengan KD tersebut supaya tujuan pembelajaran dapat tercapai. Hal ini sesuai dengan pendapat Sudjana dan Rivai 
(2015:4) yang mengatakan bahwa penggunaan media pengajaran sangat bergantung kepada tujuan pengajaran, bahan pengajaran, kemudahan memperoleh media yang diperlukan, serta kemampuan guru dalam menggunakannya dalam proses pengajaran. Hal ini senada dengan pendapat Trianto (2009:235) yang mengatakan bahwa salah satu cara agar siswa lebih semangat belajar dan berkembang menurut minatnya adalah dengan menggunakan media pembelajaran.

Validasi dan uji coba didasarkan penilaian pada tiga aspek, yaitu (1) isi, (2) wujud, dan (3) tampilan. Ketiga aspek inilah yang menentukan kepraktisan dan kemenarikan dari media yang dikembangkan. Kepraktisan berarti produk yang dihasilkan mudah digunakan oleh pengguna. Menurut Nieveen (dalam Rochmad, 2012:70), kriteria kepraktisan mengacu pada tingkat bahwa produk pengembangan dapat digunakan dan disukai dalam kondisi normal oleh pengguna. Hal ini sesuai dengan Sudjana dan Rivai (2015:5) yang berpendapat bahwa kehadiran media dalam proses pengajaran jangan dipaksakan sehingga mempersulit tugas guru, tapi harus sebaliknya yakni mempermudah guru dalam menjelaskan bahan pengajaran. Jadi, dapat dilihat bahwa media bukan sebagai keharusan, tetapi sebagai pelengkap jika dipandang perlu untuk mempertinggi kualitas belajar.

Validasi produk media audio visual untuk pembelajaran musikalisasi puisi dilakukan dengan ahli materi, ahli media, dan praktisi. Dengan ahli materi, aspek yang divalidasi adalah dari isi media pembelajaran. Kriterianya adalah (1) kualitas materi, (2) kualitas contoh, (3) kualitas tugas, (4) petunjuk penggunaan media, dan (5) keefektifan media.

Validasi produk dengan ahli media difokuskan pada isi, wujud, dan tampilan. Kriterianya adalah (1) proporsi desain layar, (2) ketepatan format media, (3) penyajian contoh, (4) penyajian petunjuk penggunaan media, dan (5) keefektifan media.

Validasi produk dengan praktisi difokuskan pada isi, wujud, dan tampilan. Kriterianya adalah (1) proporsi desain layar, (2) penyajian materi, (3) penyajian contoh, (4) penyajian tugas, dan (5) keefektifan media.

Uji coba produk dengan siswa difokuskan pada isi, wujud, dan tampilan. Kriterianya adalah (1) proporsi desain layar, (2) keefektifan media, dan (3) penyajian contoh.

Berdasarkan hasil pengembangan media audio visual untuk pembelajaran musikalisasi puisi dari proses merancang produk hingga uji validasi sudah dilaksanakan. Secara keseluruhan keempat aspek dalam media pembelajaran, yaitu isi, wujud, dan tampilan sudah memenuhi kriteria kepraktisan dan kemenarikan. Namun, media ini belum layak untuk digunakan sebagai media dalam pembelajaran musikalisasi puisi dan diimplementasikan karena belum diuji kemanfaatannya.

\section{PENUTUP}

\section{Simpulan}

Berdasarkan hasil validasi dan uji coba kepada ahli materi, ahli media, praktisi, dan siswa, media audio visual dinilai sangat valid dan dapat digunakan dalam pembelajaran musikalisasi puisi di Kelas X SMA tanpa revisi. Saran dan komentar dari ahli materi, ahli media, praktisi, dan siswa digunakan untuk melakukan revisi produk. Berbagai kendala yang sebelumnya terjadi dapat diatasi.

Saran

Berdasarkan hasil penelitian dapat diberikan beberapa saran yang berguna bagi guru bahasa Indonesia dan peneliti lain. Guru disarankan untuk menggunakan media audio visual dengan baik sesuai dengan petunjuk penggunaan media. Selain itu, guru juga bisa menyesuaikan penggunaan media dengan RPP yang telah dirancang sendiri oleh guru. Bagi peneliti lain, penelitian ini dapat dimanfaatkan sebagai bahan pertimbangan untuk mengembangkan media lain.

\section{DAFTAR PUSTAKA}

Ari, KPIN. (2008). Musikalisasi Puisi: Tuntunan dan Pembelajaran. Yogyakarta: Hikayat. Arikunto, S. (2013). Dasar-dasar Evaluasi Pendidikan. Jakarta: Bumi Aksara. 
Arsyad, A. (2002). Media Pembelajaran. Jakarta: Raja Grafindo Persada.

Heinich, dkk. (1982). Instructional Media and The New Technologies of Instruction. New York: John Willey \& Sons.

Sadiman, A. S., dkk. (2008). Media Pendidikan: Pengertian, Pengembangan, dan Pemanfaatannya. Jakarta: PT Raja Grafindo Persada.

Sanjaya, W. (2011). Perencanaan dan Desain Sistem Pembelajaran. Jakarta: Kencana.

Shinta, Y. D., Chamalah, E., \& Arsanti, M. (2018). PENERAPAN MODEL PEMBELAJARAN BERDASARKAN MASALAH DAN MEDIA VIDEO ANIMASI PERISTIWA SOSIAL BERMUATAN PENDIDIKAN MULTIKULTURAL UNTUK MENINGKATKAN KETERAMPILAN MENYUSUN TEKS EKSPLANASI. BASINDO : jurnal kajian bahasa, sastra Indonesia, dan pembelajarannya, 1(2), 59-71.

Sudjana, N dan Ahmad R. (2015). Media Pengajaran. Bandung: Sinar Baru Algesindo.

Trianto. (2009). Mendesain Model Pembelajaran Inovatif Progresif: Konsep, Landasan, dan Implementasinya pada Kurikulum Tingkat Satuan Pendidikan (KTSP). Jakarta: Kencana. 